\title{
Pandemic Among the Amish: A Look at the Effects of COVID-19 on Amish Communities in Lancaster, Pennsylvania, in the First Four Months
}

\author{
Joseph Harasta \\ Associate Professor, Communication Studies \\ Kutztown University of Pennsylvania \\ harasta@kutztown.edu
}

\begin{abstract}
March 2020 will be remembered as one of the most unusual months in living memory. When COVID-19 spread across the country, its reach and impact affected every region and every person in some way. The "new normal" forced much of the world to face a new reality of stay-at-home orders, food shortages, and rising death rates. Initially, the pandemic hit congested urban centers hardest, but the effects of the coronavirus were also felt among the rural Amish communities of Lancaster County, Pennsylvania. This study offers a preliminary look at how the pandemic affected these communities, focusing on the following themes: sources of news and information; effects of government mandates; and impact of the virus on the day-to-day lives of the Amish during the first four months of the pandemic, from late March 2020 through late July 2020. Findings suggest that the Amish experienced a mix of fear and hope, skepticism and optimism, but also a resolve in their faith, which they felt assured would carry them through the uncertainties of the coming months.
\end{abstract}

Submitted October 30, 2020; accepted May 18, 2021; published October 8, 2021

https://doi.org/10.18061/jpac.v2i1.7982

Keywords: Amish, COVID-19, coronavirus, pandemic

\section{Introduction}

The rolling hills and rural communities of Lancaster County, Pennsylvania, feel like a million miles from the East Coast urban centers of Philadelphia and New York City. But by the end of spring 2020, the county had profoundly lost its seemingly protected isolation from the problems of city life. Its location less than 70 miles from Philadelphia and only 165 miles from New York City, coupled with the tight-knit nature of its communities and villages, created the perfect context for COVID-19 to spread at an alarming pace that deeply changed every facet of life in the county. In the early weeks of the pandemic, New York City was home to the greatest concentration of COVID-19 cases, hospitalizations, and deaths in the country. Philadelphians could say the same for their city, with the most cases in Pennsylvania. The Lancaster Amish settlement, which includes Lancaster County and parts of western Chester County, is home to approximately 40,000 Amish (Young Center for Anabaptist and Pietist Studies, 2020). In the spring of 2020, the Amish in the Lancaster settlement faced not only the unprecedented problems of COVID-19, but also a host of additional complications, many stemming from their very way of life, such as a reluctance to seek preventative medical help or government assistance. Confused and inaccurate 
communication, confusion about the virus's spread and symptoms, and rejection of government interference in their lives created an atmosphere of isolation and ignorance for many.

This study seeks to describe the relationship between Amish in Lancaster County, Pennsylvania, and the COVID-19 virus. The effects of closures, misinformation, and distrust of outside intrusions are at the heart of this study's purpose. The researcher sought to speak directly to Amish community members about their feelings, experiences, and concerns as the virus spread. In contrast to traditional scholarly articles built around existing studies and literature review, this article attempts to put the reader in the context of the COVID-19 pandemic's spread in Lancaster County, Pennsylvania, as it happened, from initial reports in March to the late July reopening.

To accomplish this, the researcher utilized news and media reports on the situation as it unfolded for Amish communities in Lancaster County. The literature review focuses on what the Amish were experiencing, feeling, and living through during those early months of the virus. Based on the themes derived from this review, the author posed questions to Amish people living in Lancaster County. As of the writing of this article, large-scale academic study of the effect of COVID-19 on Amish communities are not yet published. For that reason, the article focuses on an ethnographic approach to understanding Amish perspectives to gain a deeper understanding of the phenomenon. The intent is to place readers in Lancaster County's Amish communities during the first four months of the pandemic. In addition, through firsthand accounts from health experts, community members (both Amish and non-Amish), as well as local officials, the literature review provides context for future scholars studying the pandemic's effect on Amish who might not have experienced it.

This article is intended to help contextualize the COVID-19 experience among this unique subculture that is religiously centered and rural in nature. Its conceptual framework provides unique perspectives available only during a short period of time, focused on experiences unknown in living memory. Also, this study illustrates that the Amish are engaged with wider society and are not an isolated "island unto themselves," despite stereotypes to the contrary. Because of the pandemic's long reach, no society or subculture in the United States was left untouched. Accordingly, this study also illustrates that Amish communities are heavily influenced and affected by what goes on outside their members' homes, businesses, church gatherings, and more. Moreover, this study focuses on interaction between Amish and non-Amish people, not between the Amish and an amorphous "modern society." The problems with defining "modern" and "modernization" in relation to Amish life are well known (Anderson et al., 2019). Therefore, this study aims to avoid these ambiguous and often illogical distinctions. This article posits that Amish communities share the same concerns, apprehensions, and anxieties as non-Amish communities and that the distinction between these entities is not as radical as first thought. The COVID-19 pandemic showed that the lines that had been drawn between Amish and non-Amish communities in the past are perhaps not so clear cut. The effects of closures, misinformation, fear, and distrust of outside intrusions are at the heart of this study's purpose. These effects were certainly felt by Amish communities, but they could easily be found in non-Amish communities as well. 


\section{Finding Out About a Pandemic}

Government agencies found communicating and explaining an unknown virus to the general public difficult enough but doing so with a relatively closed subgroup that shuns the widespread and instantaneous connectedness of today's media-saturated society made the effort even more challenging. As news, rumors, and fears about COVID-19 spread across the nation throughout March 2020, Amish communities in Lancaster County received the same mixed forms of information from varied sources, some saying the virus was not serious while others focused on its potential to kill thousands.

As of March 27, there were 67 confirmed cases in the county. As the case count continued to rise, Pennsylvania Governor Tom Wolf added Lancaster County to the state's list of counties with stay-at-home mandates that took effect on June 4 (City of Lancaster, n.d.). Around that same time, the Pennsylvania Office of Rural Health at Pennsylvania State University mailed pamphlets titled Plain Communities Can Protect Themselves Against COVID-19 to Old Order Amish communities across the state. The mailings had an urgent message for recipients: "Please take this virus seriously. Your family's life may depend on it," adding, "Some think that this virus is a political ploy, but that is a misconception and people of all political parties are dying" (Nark, 2020, para. 6). The quote came from noted physician and Amish genetic researcher Dr. D. Holmes Morton.

Against these voices, some publications popular in Amish communities in the county delivered muddied messages. The Fishwrapper, a free, biweekly publication popular among area Amish, noted in its March 17, 2020, edition:

What is it they fear? They worry they will pick up the virus. They panic when they think how it could affect them if they contract it. They listen to news reports that vary in their presentation - one promoting it as something to be feared and the other as nothing to worry about.

Lancaster County Conservation District Manager Christopher Thompson stated in a mid-April interview, "Some [Amish] seem surprised and unaware, others said they had heard about it but didn't think it was too big of a deal" (Sauro, 2020, para. 29). During the early phases of the pandemic, lack of epidemiological knowledge was often coupled with lack of concern. Ruth Lapp, an Amish mother, stated on March 18, "It's important that your body fight on its own...most of the time it can fight its own things. And it's not that we're against doctors, but we try to take care of ourselves first" (Ruland, 2020, para. 6).

Alice Yoder, executive director of community health for Penn Medicine Lancaster General Health, emphasized the positive feedback her hospital's outreach received: "They've [Amish] been very open, wanting to understand what COVID is about and what it meant to them.... We felt we still needed to distribute the basic information - wash your hands, practice social distancing. The basic things we all are practicing" (DeJesus, 2020, paras. 19, 21). Those communications took on grimmer connotations, however, as the pandemic spread. Lancaster Farming, a weekly newspaper 
popular among the Amish, published an extended obituary on July 24 of overall county fatalities caused by coronavirus as the death toll surpassed 300 (Lancaster Online Staff, 2020).

Alongside official word from government agencies and statements by local doctors, other sources of information competed for Amish attention. The inherent communal nature of Amish communities inevitably leads to the dissemination of news and information, whether accurate or not. "We jokingly talk about the 'Amish internet.' Information spreads by word of mouth fairly quickly," said Dr. Keith Wright, medical director at WellSpan Ephrata Hospital in northern Lancaster County (Barrett \& Wargo, 2020, para. 10). Joanne Eshleman, director of Plain Community Relations for the larger WellSpan Health System, added, "The plain community does value trusted relationships...they do really listen to the medical community when it comes to messages of public health" (Forgotch, 2020a, para. 3).

By April, several means to communicate directly to Amish communities had been developed, including the one reproduced in Figure 1.

Figure 1

State-Issued Informative Flyer Mailed to Amish Homes in Lancaster County

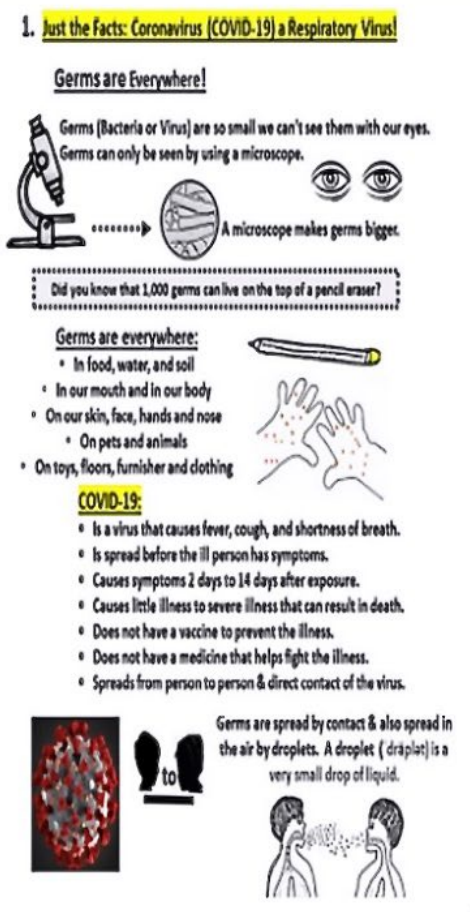

2.

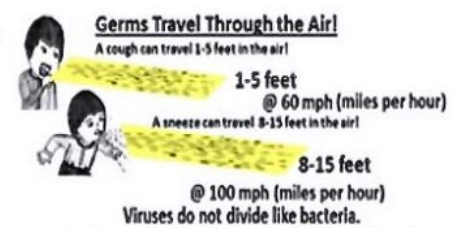
A virus goes inside a body cell and destroys the cell. Then the virus looks for another cell to destroy. COVID-19 virus goes to the lungs and can cause difficulty breathing. COVD. 19 is more catching ( 3 times more) then the fiv.
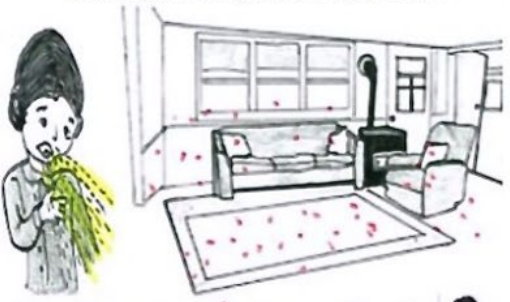

COVID-19 virus can stay on hard surfaces in a room for 2 hours to 24 hours or more

That's why it's important to block a cough or sneeze with your hand, snuppie or ellbow

And wipe down hard surfaces to reduce the amount of germs.

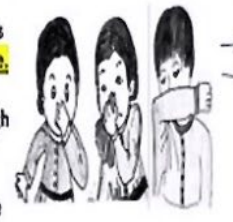

3. Facts to Help Decrease the Spread of CoviD-19
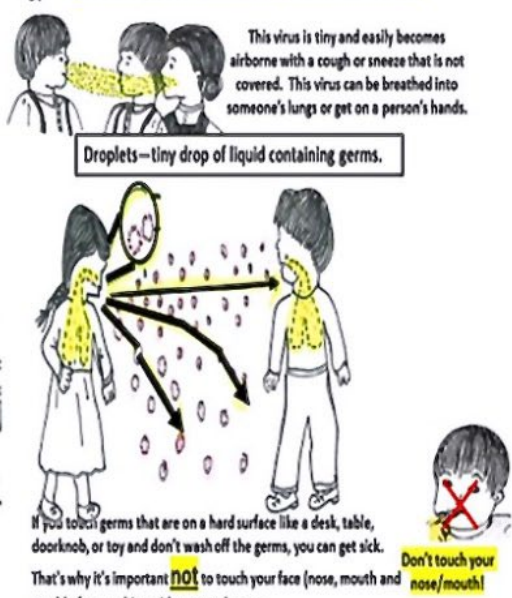

eve) before nating with 500 p and wotec.

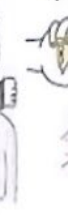

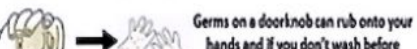

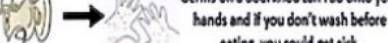
eatine rou could gort sich

hendican be speed by shating somesces stand.

Note. Note the imagery of Amish clothing and household. Source. Penn State Extension.

Summarizing the mixed sources of information, Steven Nolt, senior scholar at the Young Center for Anabaptist and Pietist Studies at Elizabethtown College, noted that "[The Amish]... have gotten messages from trusted sources. At the same time many Amish folks are also taking their cues from non-Amish neighbors and friends. In a rural context, a semi-rural context, I think we are seeing that not necessarily all Americans in those settings are responding [to public health 
directives] the same way" (DeJesus, 2020, para. 4). Referring to news images of Amish and nonAmish neighbors standing shoulder-to-shoulder, unmasked, as the New Holland Auction in late March, Nolt observed, "Many Amish folks are also taking their cues from their non-Amish neighbors" (DeJesus, 2020, para. 5).

\section{Government Mandates in a Community Wary of Government Intervention}

The very nature of Amish business and commerce in Lancaster County makes alternate means of doing business, such as remotely or non-contact alternatives via online methods, nearly impossible because much of their work requires groups of employees working in close proximity to each other. In fact, it was an Amish-owned business that was the first to be cited in Pennsylvania for violating the state's order to suspend non-life-sustaining businesses. Anonymous reports on Middle Creek Roofing's business practices resulted in state troopers issuing a citation for violating the governor's order (McKelvey, 2020). The contracting company was cited for holding meetings where employees were in close contact with one another. In early March, as the virus was first becoming widespread, Paradise Township officials tried to dissuade the Gordonville Mud Sale organizers from holding the annual two-day event that supports the village's volunteer fire company and is normally attended by hundreds of Amish and non-Amish, to no avail (King, 2020). "In their culture, they look forward to those events, to going to church and having weddings.... It's very hard on them as a culture to accept the fact that it's dangerous to do that," commented Dr. D. Holmes Morton in early April (Barrett \& Wargo, 2020, paras. 6, 7). The intrusion of state government mandates on a community that seeks to keep the state at arm's length continued to create headaches for many Amish families as case numbers and deaths continued to climb in the coming weeks.

Moreover, the effects of the stay-at-home orders were felt not only by Amish businesses reliant on commercial trade, but also by those reliant on the "Amish trade." Lancaster County touts its tourism connection, with Amish communities as one of its key attractions. "Wide open spaces await you here, from our parks and trails to recreational activities and farmers markets to roadside stands - as well as our world-famous Amish farmlands and covered bridge driving tours" (Discover Lancaster, 2020). Many of the famous Lancaster County Amish-related tourist spots such as the Amish Farm and House (see Figure 2) remained closed for weeks following the statemandated shutdown. The tourism agency devoted much time to persuasive efforts to regain its lost tourism dollars as restrictions were being lifted by mid-summer. While most Amish-owned businesses are not tourism-focused, the overall economic impact of the pandemic on the general Lancaster County economy illustrates that its effects were felt by all county residents on some level. 


\section{Figure 2}

The Amish Farm and House, Late May 2020

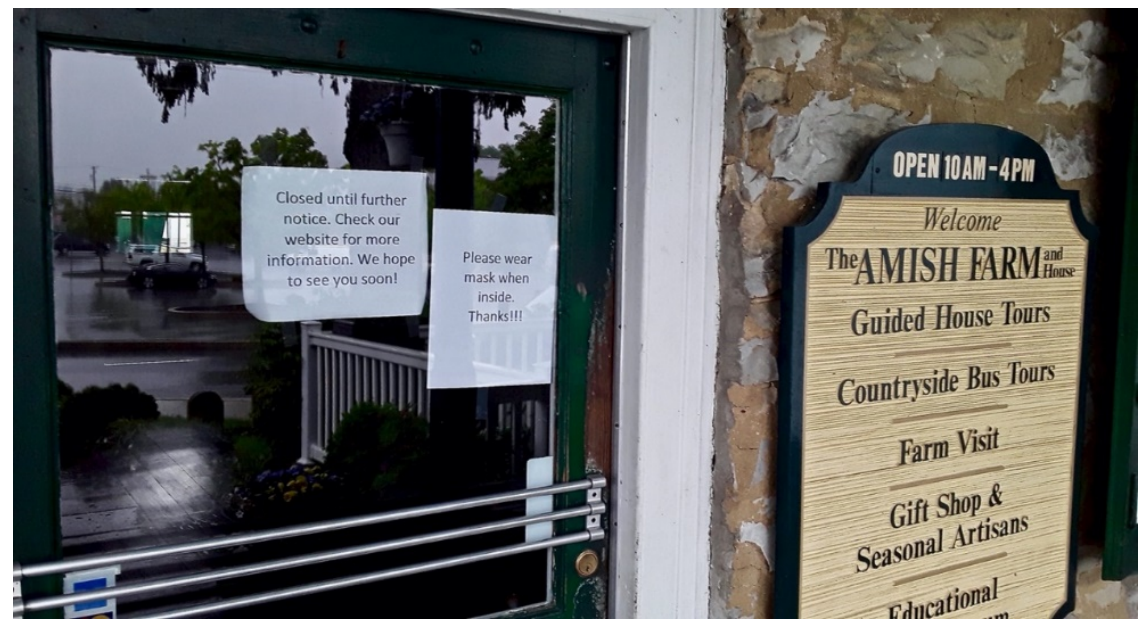

Note. The message on the window indicates that the tourist attraction is closed until further notice. (This establishment is not Amish-owned nor does it employ Amish people.)

\section{Adhering to Government Guidelines}

The mandates for shutdowns, social distancing, and mask-wearing came as Lancaster County COVID-19 cases continued to climb throughout the spring and summer. By late July, the county had over 5,000 cases with nearly 400 deaths. Figure 3 shows that the areas with the highest concentrations of deaths were in fact where many retirement and nursing home facilities are located. Such evidence might have given Amish people a sense of false security since Amish families do not house their elderly in such facilities. Accordingly, they may have felt as though the problems associated with the pandemic lie beyond their doorsteps.

\section{Figure 3}

Pennsylvania's Daily COVID-19 Dashboard showing Lancaster County's Situation in Late July 2020

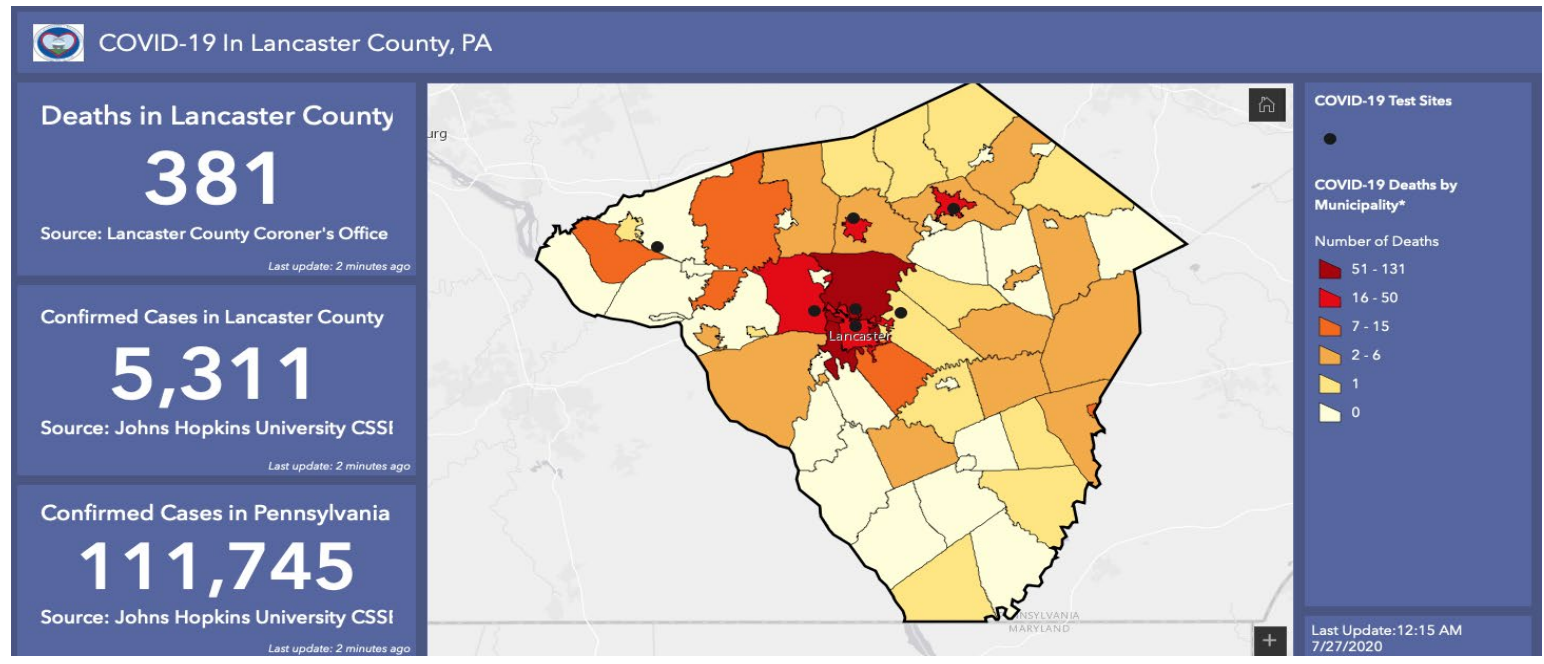


Cases continued to climb, with Lancaster County accounting for the second highest increase in Pennsylvania in June (Forgotch, 2020b). The county saw a 135\% increase in the week of June 19 to June 25 (Laughlin, 2020). Pennsylvania Secretary of Health Dr. Rachel Levine said of Lancaster County, "We have no plans to do mitigation in Lancaster County at this time, and what we want to do is work on the containment strategy" (Jorgensen, 2020, para. 11). Nevertheless, with such increases, tracking the infection rate among Amish communities was difficult. County COVID-19 public health emergency adviser Edwin Hurston noted, "We don't know, because a lot of the Amish are not being tested. They're choosing not to be tested" (Laughlin, 2020, para. 7). However, health experts agreed that Amish infection rates were likely high due to the communal nature of church gatherings and the multigenerational aspect of many Amish households, which include elderly members living at home (Link, 2021). The county attempted to hire contact tracers who spoke Pennsylvania Dutch to gain an accurate picture of the COVID-19 situation among Amish and Old Order Mennonite communities (Laughlin, 2020). However, others noted that the Amish commitment to community helped to curtail the widespread outbreak of the virus in the county. Because most of the county fatalities occurred in nursing homes, Amish community members might have held a sense of false security.

The continuous up-and-down trends of the virus in the county made the widespread reopening of many businesses difficult. Some Amish businesses never recovered from the lost revenue, mostly because they were unable or unwilling to accept direct government benefits, believing that if they took such payments they might jeopardize their exemption from Social Security and Medicare. Similar concerns produced some community discussion of how to return federal stimulus checks (Wesner, 2020).

In contrast, many non-Amish small businesses were able to utilize the CARES Act relief program, as well as changes in consumer buying habits to greater online shopping (Van Etten, 2021). In late April 2020, Lancaster County's unemployment stood at 19\%, compared to 3\% before the shutdown. Nevertheless, some were optimistic. Edward Harris, CEO of Discover Lancaster, commented, "Lancaster is a resilient place.... There is a value portion where families can come here at an affordable price and still have a great experience" (Forgotch, 2020c, para. 8). Figure 4 shows an example of the impact on Lancaster County's economy: Bird-In-Hand Farmers Market employs some Amish workers. 


\section{Figure 4}

Bird-In-Hand Farmers Market, May 2020

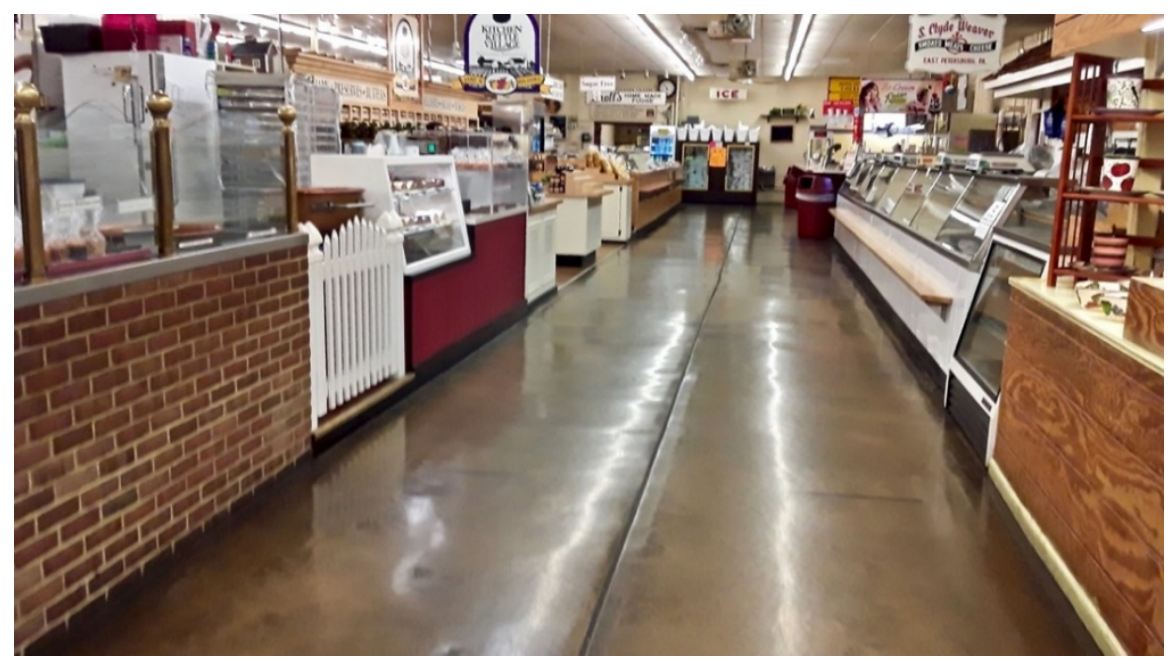

Note. The empty aisles illustrate the economic hardships facing small businesses, including those owned by Amish. Many of the market stall owners had not reopened when this photo was taken in May 2020.

Like many businesses that needed to rethink their business models, the Amish cottage industry in Lancaster County needed to adapt to the unprecedented constraints of COVID-19. Probably the most notable introduction to the Amish economy's cottage industry was the handmade face mask. Lancaster Amish sewed and donated more than 13,000 face masks to Lancaster Health Center. "Lancaster County in itself is just a very giving place," said Sylvan Stoltzfus, owner of Bird-InHand Fabric (Stauffer, 2020, para. 3). Also, Amish-made face masks could be seen for sale all over Lancaster County as early as April. However, the future of the traditional Amish economyagriculture-weighed heavily on local communities. Amish and non-Amish co-op businesses reliant on wholesale market sales saw a dramatic dip (Mekeel, 2020).

An additional problem facing Amish workers was the lack of long-distance travel abilities. Many Amish workers rely on non-Amish drivers to transport them over long distances in vans known as "Amish limousines." With non-Amish drivers staying at home, the opportunity to travel to places of work became impossible for many Amish. However, it was not just the economic changes brought on by COVID-19 that affected Amish communities. In a tight-knit society, changes and cancellations brought on by the governor's orders halted important Amish spring events like Council Sunday and preparatory service, which precede the semiannual communion service. Unlike many non-Amish events, cancellations to Amish events required community support, not just state government mandates.

County Amish leaders outlined steps to adhere to social distancing guidelines for the spring communion service, Easter, and seasonal weddings (J. Miller, 2020, para. 29): 
1. Only members of the congregation should attend the worship service. No visiting between district congregations.

2. If any member of a family is sick, the whole family should remain at home.

3. The noon meal, called the Gmeh esse, provided by the host family for the whole church, will be canceled.

4. Worship services will not be held in the hosting family's home but in a machine shed, barn or outside if the weather permits.

5. No hand shaking.

These late April guidelines seemed to contrast with earlier sentiments about the virus and its relationship to God. Mark Peachey, a caseworker for Anabaptist Financial, a financial services firm with some Amish clients, had written in mid-March:

During this uncertain time we are living in I'm thankful that we have a God that we can fully trust if we choose to do so. We do not need to live in fear of COVID19. We need to fear God. COVID19 is possibly a mercy from God to help people think about death and whether they are ready or not to meet him (Ruland, 2020, para. 11, 12).

Dr. D. Holmes Morton commented:

As typical English [non-Amish] people would, the Amish don't run to the doctor right away when there is pain. They won't be concerned about the coronavirus until someone is infected with it. It was the same with rubella, and polio, and the measles. Once there's an outbreak in their community, they get concerned (J. R. Miller, 2020, para. 10).

In addition to businesses, social events, and religious observances, Amish schools, like their non-Amish counterparts, needed to adapt to closure orders. Messiah College psychology professor Charles Jantzi noted that Amish schools were sending work home for students about twice a week, but that under ordinary circumstances, homework from Amish schools is uncommon. One Amish teacher commented, "Our schedules have dramatically changed since the virus outbreak...with no school and construction work, and families all together at home, it is making for nice family times together" (Geli, 2020, para. 11).

\section{Methods}

This study focuses on the effects of COVID-19 and resulting fallout in Amish communities in Lancaster County, Pennsylvania. In March 2020, Amish in rural and semirural areas were affected by business closures, stay-at-home mandates, and the general fear and anxiety of the unknown that was gripping the nation. Because of these unprecedented conditions, the researcher believed it was important to document the situation in Amish communities in Lancaster County, Pennsylvania, as 
it unfolded. A review of subjects was made, and Institutional Review Board approval was obtained for this study.

Participant selection was based on convenience sampling. Participants were selected as the researcher traveled the county. Most in-depth interviews (about 20 to 30 minutes long) were made at Amish home businesses where signs on main roads advertised products such as milk, cheese, and root beer (see Figure 5). The author was able to speak to varied groups of people of both genders and of many ages through this process. Shorter intercept interviews of approximately five minutes were made at businesses frequented by Amish customers that were still open during the lockdown, such as Home Depot and Wal-Mart. In all, 75 interviews were conducted between March 20 and July 1 using both methods. Field research interview responses were recorded with pen and paper, as many Amish were reticent to speak when asked if they could be recorded.

\section{Figure 5}

\section{Example of Amish Cottage Industry Advertising}

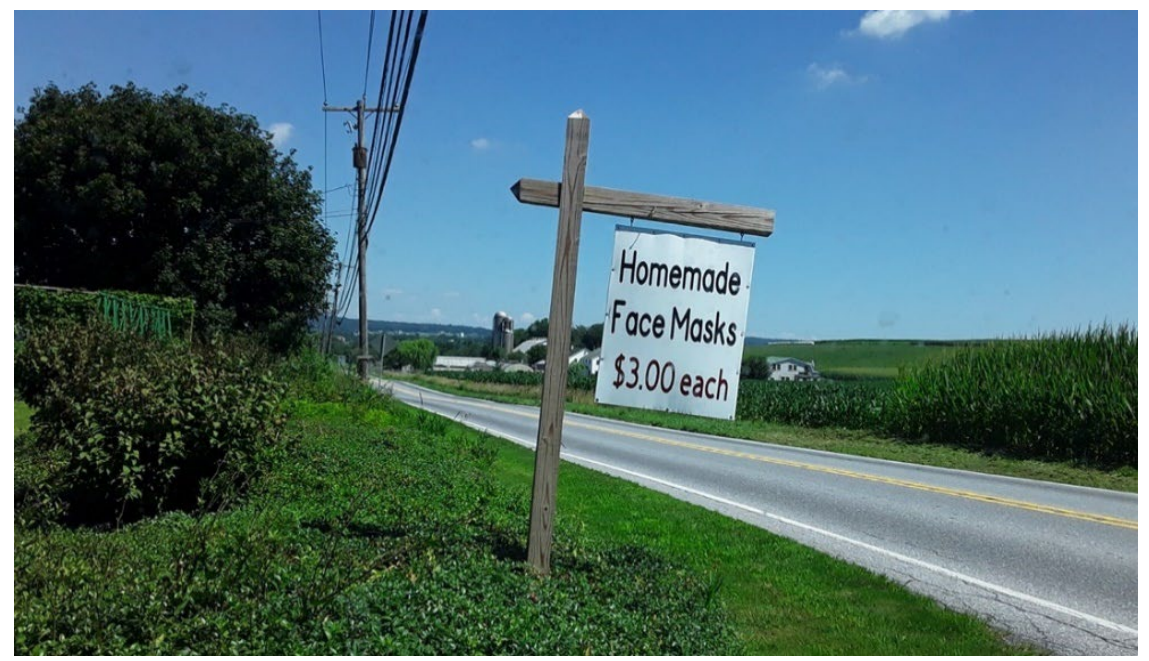

Note. An illustration of the changing face of the Amish roadside cottage industry. Similar signs advertising homemade PPE (Personal Protective Equipment) could be found in Lancaster County throughout the summer.

Data were categorized into the following themes: where/how the interviewees were getting information on the pandemic; how they were adhering to and feeling about government mandates and guidelines; the social and economic effects of COVID-19 on their families and their communities. Responses were grouped into these themes collated in numerical charts, along with poignant and illuminating direct quotes relating to them. Including direct quotes provides additional insights and reduces researcher influence and misinterpretation as much as possible. Because of the importance of time-sensitive data collection and collation and the pandemic-related isolation and uncertainties among colleagues who, during normal times, could have assisted with intercoder reliability, coding was conducted by the author. While this might affect reliability and validity, the author felt the importance of analyzing this study's unique data in a timely manner warranted the use of a single coder. The use of reflexivity was employed to reduce these problems. 
Despite its limitations, this type of empirical study aids scholarship in two ways. First, it helps show the extent to which the findings might be applied to existing scholarship. Second, it enables field researchers to easily replicate the study (Anderson et al., 2019).

The responses were collated based on their commonalities. For example, responses such as "We cannot travel far because our driver is at home" and "The place I worked is closed" are placed in the same category because they both relate to the respondent's inability to work due to stay-athome restrictions. Responses in this study are not necessarily reflective of the entire Amish population in Lancaster County since the individuals included in this study were those willing to speak with the researcher. Many respondents did not want to reveal demographic information such as contact information; therefore, including this data in the results is limited to those who were willing to share personal details.

\section{Results}

Interview responses were grouped into the three main themes investigated in this study: (a) where and how respondents were getting information on the pandemic, (b) how they were adhering to and feeling about government mandates and guidelines, (c) the economic effects of COVID-19 on their families and their communities. Most detailed, in-depth responses came from visits to Amish farms that advertised a cottage industry product for sale. Briefer but to-the-point responses were obtained at retail establishments whenever the researcher spotted Amish customers.

\section{General Sentiments on Where and How the Amish Were Getting Information on the Pandemic}

Table 1 provides a summary of this theme's results, showing the frequency of responses to questions posed about it. Nearly all respondents were aware of the pandemic by early April; however, some were skeptical of its impact. Commented one Amish woman, "It's like anything else, a bunch of hype from the news." Another said, "Right, it'll be gone and forgotten and replaced with something new." Other respondents were more inclined to believe its impact. "I'm afraid for my children and father. They say they'll get it first," said one. "We'll be ok as long as we keep away from people," said another. Some unexpected responses connected the pandemic to politics. "It's a way to get Trump out of there. They don't like him," remarked one Amish man. When asked who "they" were, he responded, "The Democrats. They made this up about him." A young Amish man standing nearby commented, "Trump's doing too good. They have to bring him down." Perhaps reflecting the views and news received from neighbors and coworkers, Amish respondents who gave the impression of supporting Donald Trump were also more apt to say the pandemic was a hoax. "Like everything, it's made up to scare people. It's not real. Politics as usual," said one. A sense of practicality about precautions characterized many Amish responses regarding health measures. The focus on immediate health care concerns versus long-term preventative measures aligns with much of the literature on the topic (Anderson \& Potts, 2020). This illustrates the concerns and reluctance that many Amish communities share about health care, which are more pronounced with COVID-19 vaccinations (Scott et al., 2021). 


\section{Table 1}

Interview Themes and Frequencies-Sources of Information on the Pandemic for Amish in Lancaster County, Pennsylvania

\begin{tabular}{lr}
\hline Question & $n$ \\
\hline Where did you first hear about the coronavirus? & 35 \\
$\quad$ Friends & 21 \\
Family & 12 \\
Coworkers & 7 \\
News & \\
How do you feel about the news you're hearing? & 37 \\
Uncertain & 21 \\
Not worried & 13 \\
Scared & 4 \\
Hoax & \\
How do you think it will play out? & 45 \\
It will blow over & 16 \\
It will be here for a long time & 14 \\
Wait and see & \\
What's affecting your opinions about it? & 23 \\
No one seems to know anything & 52 \\
What my parents and/or church leaders say
\end{tabular}

The overwhelming majority of respondents pointed to the lack of concrete information on the pandemic from the outside world as the key element affecting their thoughts on it. "They don't know, we don't know. Nobody knows," was typical of many responses. When asked where they were getting information on the pandemic, respondents noted several sources including newspapers, neighbors, non-Amish, and word-of-mouth, which seemed to be the most prevalent source. "I hear things from different people. Some say it's bad, others not," remarked one. "Most of what we get comes from the men and boys who work outside the community. They pick up pieces here and there," said another. Most of the sources of news seemed to come from non-Amish coworkers or drivers. "Dan [a driver] updates us about every day. But he says they don't know much either," said one respondent. "We get the paper and read from time to time about it," was also a common response, "People are all in a tizzy about it."

Questions about their sources of information often evolved into discussions about spirituality and faith. "We put our faith in the Lord to protect us, and if he wants us to come now, we will," was also a common type of answer to questions about the pandemic. "I'm ready to go at any time, and if this is the time for us all to go, then it might be a blessing," said one. "We get these things in the mail that show us what's going on, but as long as we keep the faith, we'll stay safe and the Lord will protect us," commented another respondent. "The leadership of the community and church explain what we need to know and do. I trust them," was also typical of many answers. 
Most interviewees were confident that the pandemic would be short-lived. "I'm worried, but I'm not at the same time. There's nothing I can do about it besides stay safe and clean," was another response.

\section{General Sentiments on How the Amish are Adhering to and Feeling about Government Mandates and Guidelines}

Several responses on government requirements and mandates stemming from the pandemic reflected the Amish lifestyle and its independence from relying on the outside world. (See Table 2.) "Right now, we're not too put out by staying home. We have everything we need here for a long time," said one Amish farmer. "I think we got you [non-Amish] beat on this," remarked another. "I'm here most of the time anyway," said an Amish woman. Others, however, were more concerned about the economic impact the mandate was having on their families.

\section{Table 2}

Interview Themes and Frequencies-How Amish in Lancaster County, Pennsylvania, Feel about Adhering to Government Mandates and Guidelines

\begin{tabular}{lc}
\hline Question & $n$ \\
\hline How have the state's stay-at-home orders affected you? & \\
Negatively, it affects my (or someone in my family's) ability to work & 35 \\
Positively, more family time at home & 27 \\
No effect & 13 \\
How have the state's mask and social distancing mandates affected you? & \\
Cannot hold church meetings regularly & 62 \\
Cannot meet with friends and family as often & 7 \\
Unsure & 4 \\
No effect & 2 \\
How have the state's closures of nonessential businesses affected you? & \\
No effect & 56 \\
Cannot go to local restaurants/food options & 8 \\
Cannot shop where I used to & 9 \\
\hline
\end{tabular}

"My son can't go to his job because it's too far away, and the driver isn't going out anymore," reflected common concerns about commuting problems. "We don't have the same freedom to get out like we used to. But I guess no one can now," said another. "Trying to find some way of getting to the job sites is a real problem for a lot of people now. Even the ones who used to take us way to New Jersey aren't really going that much anymore," said a farmers' market employee.

Largely, however, it was the requirements of social distancing that seemed to have the greatest impact on Amish communities. The loss of socialization and religious services seemed to weigh heaviest. "We just can talk with those who live with us. They don't have the school opened now, so the kids can't see their friends and play their games either," said one respondent. "I miss the 
small get-togethers with the neighbors. We tried meeting outside, but it's too cold still for that," said an interviewee on a particularly chilly April day. "I think things will get back to normal soon. The summer will be better," was a typical response to questions posed throughout the spring. Answers to questions relating to stay-at-home orders were more optimistic once warm weather arrived. "We meet out by the big tables there," said one respondent pointing to several picnic tables lined up in the yard. "We're out here in the evenings mostly and on Sundays, so it's not that much different." However, missed religious services and holidays were much more worrisome than informal socializations.

"We didn't really have our normal Easter services or dinner this year. Doesn't seem like it's right," replied an elderly Amish woman. "Losing the Sunday meetings like we do them is really hard on most of us. We really look forward to them," said another interviewee. "It's spring outside, but it's not the same somehow when you can't have things the way you're used to," and "I thought it'd be back to normal by Ascension Day [May 21]," were typical of responses related to spring holidays. "I miss the sound of the singing and the bishop's message," replied one. "I pray we can get back together like we used to, but that's in God's hands. My son is getting married soon, and I pray we can have a proper wedding for him," said another.

The nonessential business closures, on the other hand, seemed to have minimal effect on those interviewed. "Wal-Marts are open. That's the only place I go regularly, but it's not a big deal if I don't," said one young Amish woman. "There's nothing they have that I can't live without," was a common sentiment when asked about nonessential business closures. Interestingly, hypermodernity, which helps to characterize non-Amish society as distinct from Amish society (Kraybill et al., 2013), broke down or at least slowed substantially during the pandemic's early weeks. The near-immediate closures, restrictions, and rationing that affected much of society enabled the Amish to continue with their way of life less encumbered than the world outside their communities as many Amish households preserve foods and maintain food stores that are less common among non-Amish.

\section{General Sentiments on the Economic Effects of COVID-19 on Lancaster County, Pennsylvania, Amish Communities}

Table 3 focuses on the primary commonality between Amish communities and their non-Amish counterparts: the effect that COVID-19 had on their pocketbooks. Many interviewees felt the hit from closures and from the fact that so many people were now staying at home. On the other hand, some noted that the problems with low local supermarket stocks had actually helped them. There did, however, appear to be an optimistic tone to their responses regardless. 


\section{Table 3}

Interview Themes and Frequencies-How COVID-19 Has Affected the Amish Economy in Lancaster County, Pennsylvania

\begin{tabular}{lr}
\hline Question & $n$ \\
\hline Have you been affected economically since the pandemic started? & 68 \\
Yes & 3 \\
No & 4 \\
Somewhat & 27 \\
How has the coronavirus monetarily cost you? & 16 \\
$\quad$ Loss of customers & 11 \\
Inability to work & 21 \\
People do not have money to spend & \\
Fearful of future (i.e., saving money for whatever might come) & 45 \\
Are you doing anything differently now for money? & \\
Selling different, new products, or will try hand at selling & 21 \\
something in the meantime & 9 \\
Selling more staples (i.e., eggs, milk, cheese) & \\
Keeping more sale products back for family or unsure & \\
What do you see for the future for you and your community when it & \\
comes to economics? & 32 \\
$\quad$ Things will get better soon & 22 \\
Things will get worse before they get better & 17 \\
Selling more products & 4 \\
Better crops and harvests & \\
\hline
\end{tabular}

"We simply can't get to the places where we used to sell our items. I heard they won't even let us leave the state now," said one Amish merchant. Another noted the problems with getting materials and ingredients to produce items to sell. "The shelves are empty of flour and sugar and such," lamented one Amish woman. The main problem identified was the loss of customers for cottage industry and farmers' market businesses. "We open at the market, but lately no one is really there. We spend most of the time standing around when we used to be so busy," said one. "I think a lot of people [customers] don't want to come out now. They're afraid. I think they can just get it ordered on the internet and have it come to their home now," replied another respondent. However, for some, the pandemic offered unique opportunities despite the problems it brought.

"We're sewing and selling and donating a lot of masks now. We did a couple hundred so far," said one interviewee. Ironically, the problems some felt from the lack of products on grocery store shelves turned into opportunities for others. "We have eggs. We have milk. We sometime make bread and stuff. A lot more people are coming to get that stuff than before," said one, adding, "I think people think we're safer than the stores now. Maybe it's good they're getting back to the basics in life." Generally, more interviewees seemed hopeful about the economic future than seemed fearful or pessimistic about it. 
"We lost a lot of holiday [Easter] customers, but I think once the weather turns, it will get back to normal," said a stand owner at a farmers market. "There's a lot of panic right now. Once things settle down, it will be like it was before," said another.

By summer, most of the customers had returned to the Amish markets and businesses. "They couldn't get a lot of the stuff we have at the grocery store, so they come here," said one. "Things seem to be rebounding. We were packed a while ago," said another respondent, following the Fourth of July.

\section{Discussion}

This study should be seen as a snapshot in time. It looks at the responses of a select number of Amish in Lancaster County, Pennsylvania, from late March to late July 2020. It is not reflective of the region's entire Amish community. Additionally, because of COVID-19's unpredictability, this study should also be seen as a part of a continuing study as the pandemic continues its cyclical pattern of escalation and reduction. For example, the effect of widespread vaccine availability on the pandemic remains unclear as of this writing.

Data from this study can best be described as paradoxical. Persons interviewed early on characterized the pandemic as hype, hysteria, and hoax. However, those interviewed later, as the situation grew direr, accepted and even embraced some of the requirements imposed on them to keep their communities safe. The loss of revenue and livelihood affected many greatly; however, some saw the stay-at-home requirements as blessings that resulted in more family time. Forced closures increased anxieties and pressures on those reliant on work outside the community, while others benefitted from cottage industry and new product sales. Some members of this community, which is traditionally apolitical, seemed to have newfound support for the country's political leadership, possibly because of campaign targeting (Zauzmer, 2019). Past research showing Amish ambivalence to national politics and the political system (Kraybill, 2014) appeared contradicted by the polarizing effects of the pandemic. Responses seemed to indicate that the loss of church and social gatherings led many to a faith reinforced and the value of relationships renewed. The dichotomous nature of these responses illustrates the many perplexities that COVID-19 forced on their lives, such as greater government intervention, increased political focus, and more media attention.

Choy's (2020) assertion that Amish families are typically poorer than non-Amish because "Amish community rules reduce economic productivity" (p. 730) stands in contrast with pandemic limitations and shortages experienced greatest by non-Amish communities. The pandemic counters the notion that Amish members have lower quality of life and welfare than non-Amish (Choy, 2020). In fact, this study shows that the unprecedented events of 2020 left some Lancasterarea Amish believing they possessed stronger mechanisms of economic health, as well as greater social means to cope with the pandemic, than their non-Amish neighbors. The unique, independent nature of Amish life enabled them to thrive when many around them faced overwhelming economic and social hardships as the pandemic continued and Amish communities were better able to react and overcome the hardships from the early days of the pandemic. 
Responses from Amish participants in this study in Lancaster County, Pennsylvania, point to a people experiencing a mix of anxiety, uncertainty, fear, and hope when it came to the effects of COVID-19 on their communities. Many of these emotions mirrored those of the nation at the time. The isolation and separation that many interpret as the Amish way might not be as far removed from their own lives as they think. While horse-and-buggy transportation and plain clothes might visually separate Amish from their non-Amish neighbors, they experienced the same emotions and trepidations as everyone. Unlike most of the secular world, though, the Amish view this life as just a brief passage of time before entering their everlasting world. Because of this, many respondents felt as though whatever happens on Earth is God's will and not to be questioned. While they understood the dangers and accepted the restrictions placed on their ways of life because of the pandemic, they were not embittered or resentful of them. Old Order resistance to accept health care measures they do not deem as immediately needed (Miller et al., 2017) also appeared contradictory by their use and manufacture of face masks. The social and economic changes imposed on them were certainly not welcomed, but rather were simply accepted.

The general feeling from the interviewees was that of resolve. Interviews revealed a people caught in the whirlwind of anxiety and unease, but also optimistic about the future and assured and confident in their faith. Finally, this study shows that Amish society often works at what might seem like polar opposites at first glance. The cultural negotiation seen in many Amish communities (Kraybill, 2001) is reinforced in this study's findings. Their ability to adapt and adjust is one of the defining characteristics of the Amish. Like all of us, the Amish had to face the realities of the

pandemic, accept its uncertainties, and look forward to a day when the "new normal" returns to what we all remember as the old normal.

\section{References}

Anderson, C., \& Potts, L. (2020). The Amish health culture and culturally sensitive health services: An exhaustive narrative review. Social Science \& Medicine, 265.

https://doi.org/10.1016/j.socscimed.2020.113466

Anderson, C., Donnermeyer, J., Longhofer, J., \& Reschly, S. D. (2019). A critical appraisal of Amish Studies' de facto paradigm, "Negotiating with modernity." Journal for the Scientific Study of Religion, 58(3), 725-742. https://doi.org/10.1111/jssr.12600

Barrett, M., \& Wargo, M. (2020, April 11). Authorities work to keep Amish communities informed amid coronavirus pandemic. NBC News. https://www.nbcnews.com/news/usnews/authorities-work-keep-amish-communities-informed-amid-coronavirus-pandemic$\underline{\mathrm{n} 1181191}$

Choy, J. P. (2020). Religious rules as a means of strengthening family ties: Theory and evidence from the Amish. Journal of Comparative Economics, 48(3), 729-748.

https://doi.org/10.1016/j.jce.2019.12.007

City of Lancaster. (n.d.). Stay at home order. https://www.cityoflancasterpa.com/covid-19-stayat-home-order/ 
DeJesus, I. (2020, April 6). The Amish present unique challenges amid coronavirus. Penn Live/Patriot News. https://www.pennlive.com/coronavirus/2020/04/the-amish-presentunique-challenges-amid-coronavirus.html

Discover Lancaster. (2020). Lancaster tourism continues to emerge from COVID-19. https://www.discoverlancaster.com/lancaster-county-during-coronavirus-covid-19/

Fishwrapper. (2020, March 17). Editorial, 3.

Forgotch, A. (2020a, April 2). COVID-19 warnings spread in the Amish community. ABC27

News. https://www.abc27.com/news/local/lancaster/covid-19-warnings-spread-in-the-amishcommunity/

Forgotch, A. (2020b, June 30). Covid-19 cases growing at 2nd highest rate throughout PA in Lancaster County. ABC27 News. https:/www.abc27.com/news/local/lancaster/covid-19cases-growing-at-2nd-highest-rate-throughout-pa-in-lancaster-county/

Forgotch, A. (2020c, June 30). Tourism industry hopes to rebound after coronavirus pandemic. $A B C 27$ News. https://www.abc27.com/news/local/lancaster/tourism-industry-hopes-torebound-after-coronavirus-pandemic/

Geli, A. (2020, June 6). Amish schools: "Distance learning” involves paper and pencil. Associated Press. https://apnews.com/article/1519448d02ee4d178fee78875b16ea6e

Jorgensen, M. (2020, June 30). Lancaster County sees steady rise in COVID-19 cases over last week. WGAL. https://www.wgal.com/article/lancaster-county-sees-steady-increase-incoronavirus-cases-over-last-week/33013114

King, A. (2020, March 12). Gordonville mud sale to go on this weekend despite township officials encouraging cancellation. LNP Lancaster Online.

https://lancasteronline.com/news/local/gordonville-mud-sale-to-go-on-this-weekend-despitetownship-officials-encouraging-cancellation/article_7675ccaa-63d9-11ea-a4c063959fd40d06.html

Kraybill, D. B. (2001). The riddle of Amish culture. (Rev. ed.). Johns Hopkins University Press.

Kraybill, D. B. (2014). Opting out: How the Amish have survived in America. Commonwealth, 141(5), 13.

Kraybill, D. B., Johnson-Weiner, K. M., \& Nolt, S. M. (2013). The Amish. Johns Hopkins University Press.

Lancaster Online Staff (2020, July 24). Coronavirus deaths pass 300 in Lancaster County: Here are some of the lives we've lost to the pandemic. Lancaster Farming. https://www.lancasterfarming.com/coronavirus-deaths-pass-300-in-lancaster-county-hereare-some-of-the-lives-weve-lost/article 4aa6c875-5322-5fbb-943a-a62431924e1e.html

Laughlin, J. (2020, June 27). More COVID cases in Lancaster County raise concerns as officials seek to determine virus' spread among Amish. The Philadelphia Inquirer. https://fusion.inquirer.com/health/coronavirus/lancaster-covid-coronavirus-amish-spreadpositive-test-pennsylvania-20200627.html 
Link, D. (2021, February 10). Fact check: Amish communities have been affected by COVID-19 pandemic. USA Today. https:/www.usatoday.com/story/news/factcheck/2021/02/10/factcheck-false-claim-amish-dont-get-covid-19/4455551001/

McKelvey, W. (2020, April 24). State police cite Amish contractor for violating coronavirus non-essential order. Penn Live Patriot-News. https://www.pennlive.com/news/2020/04/statepolice-issue-first-citation-for-violating-coronavirus-non-essential-business-order.html

Mekeel, T. (2020, May 2). Growing confusion: COVID-19 creates uncertainty for wholesale greenhouse and retail garden centers. LNP Lancaster Online.

https://lancasteronline.com/business/local_business/growing-confusion-covid-19-createsuncertainty-for-wholesale-greenhouse-and-retail-garden-centers/article 03c775fe-8b26-11 eaa075-c3cb328559b7.html

Miller, J. (2020, April 27). Pandemic disrupts Plain life. Anabaptist World. https://anabaptistworld.org/pandemic-disrupts-plain-life/

Miller, J. R. (2020, March 19). Pennsylvania's Amish community not "as spooked" by coronavirus, mothers say. New York Post. https://nypost.com/2020/03/19/pennsylvaniasamish-community-not-as-spooked-by-coronavirus-mothers-say/

Miller, K., Yost, B., Abbott, C., Thompson, S., Dlugi, E., Adams, Z., Schulman, M., \& Strauss, N. (2017). Health needs assessment of Plain populations in Lancaster County, Pennsylvania. Journal of Community Health, 42(1), 35-42. https://doi.org/10.1007/s10900016-0223-5

Nark, J. (2020, March 27). For Pennsylvania's Amish, the coronavirus and the call for social distancing are a challenge. Philadelphia Inquirer. https://www.inquirer.com/news/amishcoronavirus-religion-covid-pennsylvania-masks-20200327.html

Ruland, S. (2020, March 19). "We aren't as spooked": How the Amish are responding to the coronavirus. York Daily Mirror. https:/www.ydr.com/story/news/2020/03/18/pacoronavirus-how-amish-community-responding/2864752001/

Sauro, S. (2020, April 11). "Not trying to stick our head in the sand": Most Amish aware of COVID-19 danger, taking precautions. LNP Lancaster Online.

https://lancasteronline.com/not-trying-to-stick-our-head-in-the-sand-most-amish-aware-ofcovid-19/article fd605552-7b5b-11ea-8f23-e7b927a5fc2a.html

Scott, E. M., Stein, R., Brown, M. F., Hershberger, J., Scott, E. M., \& Wenger, O. K. (2021). Vaccination patterns of the northeast Ohio Amish revisited. Vaccine, 39(7), 1058-1063. https://doi.org/10.1016/j.vaccine.2021.01.022

Shannon, A. (2020, May 25). Lancaster County tourism takes hit during COVID-19 pandemic. WGAL. https:/Www.wgal.com/article/lancaster-county-tourism-takes-hit-during-coronaviruspandemic/32662607

Stauffer, H. (2020, March 25). Amid nationwide shortage of masks, Amish are sewing 13,000 to donate in Lancaster County. LNP Lancaster Online. https://lancasteronline.com/news/local/amid-nationwide-shortage-of-masks-amish-are- 
sewing-13-000-to-donate-in-lancaster-county/article 38bf6728-6e00-11ea-9b65-

b7c21f65bc45.html

Van Etten, A. (2021, May 26). Lancaster experts discuss post-pandemic outlook for small businesses. ABC 27 News. https://www.abc27.com/news/local/lancaster/lancaster-expertsdiscuss-post-pandemic-outlook-for-small-businesses/

Wesner, E. (2020, May 27). Amish returning COVID-19 stimulus checks. Amish America. https://amishamerica.com/amish-returning-covid-19-stimulus-checks/

Young Center for Anabaptist and Pietist Studies. (2020). Twelve largest Amish settlements, 2020. Amish Studies. http://groups.etown.edu/amishstudies/statistics/twelfth-laregest-settlements$\underline{2020 /}$

Zauzmer, J. (2019, October 9). The famously secluded Amish are the target of a Republican campaign to drum up Pennsylvania votes for Trump. The Washington Post.

https://www.washingtonpost.com/religion/2019/10/09/famously-secluded-amish-are-targetrepublican-campaign-drum-up-pennsylvania-votes-trump/ 